\title{
Nitrous oxide fluxes and nitrogen cycling along a pasture chronosequence in Central Amazonia, Brazil
}

\author{
B. Wick ${ }^{1}$, E. Veldkamp ${ }^{2}$, W. Z. de Mello ${ }^{3}$, M. Keller ${ }^{4}$, and P. Crill ${ }^{5}$ \\ ${ }^{1}$ Humboldt University Berlin, Department of Soil Science and Site Science, Invalidenstr. 42, 10115 Berlin, Germany \\ ${ }^{2}$ Institute of Soil Science and Forest Nutrition, Georg August University Göttingen, Büsgenweg 2, 37077 Göttingen, Germany \\ ${ }^{3}$ Universidade Federal Fluminense, Instituto de Química, Departamento de Geoquímica, Centro, Niterói, RJ, CEP \\ 24.020-007, Brasil \\ ${ }^{4}$ USDA Forest Service, International Institute of Tropical Forestry, Jardin Botanico Sur, 1201 Calle Ceiba, San Juan, PR \\ 00926-1119, USA \\ ${ }^{5}$ Department of Geology and Geochemistry, University of Stockholm, 10691 Stockholm, Sweden
}

Received: 4 March 2005 - Published in Biogeosciences Discussions: 4 May 2005

Revised: 11 July 2005 - Accepted: 14 July 2005 - Published: 2 August 2005

\begin{abstract}
We studied nitrous oxide $\left(\mathrm{N}_{2} \mathrm{O}\right)$ fluxes and soil nitrogen $(\mathrm{N})$ cycling following forest conversion to pasture in the central Amazon near Santarém, Pará, Brazil. Two undisturbed forest sites and 27 pasture sites of 0.5 to 60 years were sampled once each during wet and dry seasons. In addition to soil-atmosphere fluxes of $\mathrm{N}_{2} \mathrm{O}$ we measured 27 soil chemical, soil microbiological and soil physical variables.

Soil $\mathrm{N}_{2} \mathrm{O}$ fluxes were higher in the wet season than in the dry season. Fluxes of $\mathrm{N}_{2} \mathrm{O}$ from forest soils always exceeded fluxes from pasture soils and showed no consistent trend with pasture age. At our forest sites, nitrate was the dominant form of inorganic $\mathrm{N}$ both during wet and dry season. At our pasture sites nitrate generally dominated the inorganic $\mathrm{N}$ pools during the wet season and ammonium dominated during the dry season. Net mineralization and nitrification rates displayed large variations. During the dry season net immobilization of $\mathrm{N}$ was observed in some pastures. Compared to forest sites, young pasture sites ( $\leq 2$ years) had low microbial biomass $\mathrm{N}$ and protease activities. Protease activity and microbial biomass $\mathrm{N}$ peaked in pastures of intermediate age (4 to 8 years) followed by consistently lower values in older pasture (10 to 60 years). The $\mathrm{C} / \mathrm{N}$ ratio of litter was low at the forest sites $(\sim 25)$ and rapidly increased with pasture age reaching values of 60-70 at pastures of 15 years and older.

Nitrous oxide emissions at our sites were controlled by $\mathrm{C}$ and $\mathrm{N}$ availability and soil aeration. Fluxes of $\mathrm{N}_{2} \mathrm{O}$ were negatively correlated to leaf litter $\mathrm{C} / \mathrm{N}$ ratio, $\mathrm{NH}_{4}^{+}-\mathrm{N}$ and the ratio of $\mathrm{NO}_{3}^{-}-\mathrm{N}$ to the sum of $\mathrm{NO}_{3}^{-}-\mathrm{N}+\mathrm{NH}_{4}^{+}-\mathrm{N}$ (indicators of $\mathrm{N}$ availability), and methane fluxes and bulk density (indicators of soil aeration status) during the wet season. During the dry season fluxes of $\mathrm{N}_{2} \mathrm{O}$ were positively correlated to
\end{abstract}

Correspondence to: $\mathrm{B}$. Wick

(barbara.wick@agrar.hu-berlin.de) microbial biomass $\mathrm{N}, \beta$-glucosidase activity, total inorganic $\mathrm{N}$ stocks and $\mathrm{NH}_{4}^{+}-\mathrm{N}$. In our study region, pastures of all age emitted less $\mathrm{N}_{2} \mathrm{O}$ than old-growth forests, because of a progressive decline in $\mathrm{N}$ availability with pasture age combined with strongly anaerobic conditions in some pastures during the wet season.

\section{Introduction}

Over the past two decades deforestation rates in the Brazilian Legal Amazon have averaged nearly $20000 \mathrm{~km}^{2}$ per year (Houghton et al., 2000). The majority of the cleared area has been converted into cattle pastures (Nepstad et al., 1997). Clearing of tropical forests for pastures is thought to be an important source of greenhouse gas emissions, such as nitrous oxide $\left(\mathrm{N}_{2} \mathrm{O}\right)$, methane $\left(\mathrm{CH}_{4}\right)$ and carbon dioxide $\left(\mathrm{CO}_{2}\right)$ (IPCC, 2001). Studies in tropical America so far have revealed contrasting patterns of $\mathrm{N}_{2} \mathrm{O}$ fluxes following forest clearing and pasture establishment. Most studies in Amazonia have shown that (-unfertilized-) pastures emit less $\mathrm{N}_{2} \mathrm{O}$ and NO than old growth forest sites (Goreau and de Mello, 1985, 1988; Verchot et al., 1999; Melillo et al., 2001; GarciaMontiel et al., 2001). Most exceptions to this general finding were measured either on sites which had been fertilized (Luizão et al., 1989; Matson et al., 1990) or were short-term studies measured once during the rainy season (Luizão et al., 1989). The only year-round study where elevated $\mathrm{N}_{2} \mathrm{O}$ fluxes were reported from a pasture was the study by Melillo et al. (2001) who measured elevated $\mathrm{N}_{2} \mathrm{O}$ fluxes from a newly created pasture in central Rondônia during the first 2 years after establishment. Pastures older than 3 years emitted less $\mathrm{N}_{2} \mathrm{O}$ than the forest.

(C) 2005 Author(s). This work is licensed under a Creative Commons License. 
Studies outside Amazonia have shown that compared to original forest, elevated $\mathrm{N}_{2} \mathrm{O}$ and $\mathrm{NO}$ fluxes may occur in young pastures (Keller et al., 1993; Veldkamp et al., 1999). Pastures older than 10 years all have low to very low emissions (Keller et al., 1993; Veldkamp et al., 1999; Erickson et al., 2001) unless they are fertilized (Veldkamp et al., 1998; Mosier and Delgado, 1997). Davidson et al. (2000) showed that the wide variations in observed $\mathrm{N}_{2} \mathrm{O}$ and $\mathrm{NO}$ emissions across a range of tropical forest and (-unfertilized-) pasture sites (in Brazil, Costa Rica, and Puerto Rico) were primarily controlled by $\mathrm{N}$ availability and soil water conditions. Where $\mathrm{N}$ availability was low, $\mathrm{N}_{2} \mathrm{O}$ fluxes were also always limited. Where $\mathrm{N}$ availability was high, $\mathrm{N}_{2} \mathrm{O}$ fluxes were elevated under high soil moisture conditions. How land use change affects $\mathrm{N}_{2} \mathrm{O}$ and $\mathrm{NO}$ budgets at landscape scale was studied by Plant (2000) and Reiners et al. (2002) for NE Costa Rica. Using data-intensive models they showed that the integrated landscape responses depended on both edaphic factors and management.

In the Amazon basin, studies on $\mathrm{N}_{2} \mathrm{O}$ emissions together with indices of $\mathrm{N}$ cycling have been published so far only from Paragominas, eastern Amazonia (Verchot et al., 1999) and from Rondônia in the south-western Brazilian Amazon (Melillo et al., 2001; Garcia-Montiel et al., 2001). A comprehensive study comparing $\mathrm{N}_{2} \mathrm{O}$ fluxes and indices of $\mathrm{C}$ and $\mathrm{N}$ cycling in pastures of contrasting age has not yet been published for the central Amazon. But we need this additional research to refine our understanding of the magnitude of the changes and the controls on key biogeochemical processes to develop predictions of the consequences of changes in land cover and land use across the Amazon basin. The objective of the present study was to determine the effects of forestto-pasture conversion and pasture age (time following deforestation) on soil $\mathrm{N}$ cycling and related $\mathrm{N}_{2} \mathrm{O}$ fluxes near Santarém, Pará in the central Amazon. In our study we used a space-for-time substitution which is a common approach to study the effects of forest clearing and pasture age on trace gas fluxes (e.g. Keller et al., 1993; Veldkamp et al., 1999; Verchot et al., 1999; Melillo et al., 2001; Garcia-Montiel et al., 2001). Space-for-time replications can be an efficient way to generalize qualitative trends and create hypotheses (Pickett, 1989; Fleming, 1999). The main disadvantages of this method involving forest-to-pasture chronosequences have been discussed by Veldkamp et al. (1999): (1) spatial variability is included in the experimental design and may appear as variability caused by time (see also Pickett, 1989); (2) short-term measurements may not be sufficient to derive a good estimate of a parameter; (3) site history is uncertain, i.e. unrecognized effects in the past of a system may be of large magnitude (Pickett, 1989). Because of these problems, Veldkamp et al. (1999) recommended temporal and spatial replication. In the present study we selected a chronosequence of forest $(n=2)$ and pasture sites of contrasting age $(n=27)$. We sampled once during the wet season and once during the dry season at a large number of sites. Our goal was not to provide an accurate estimate of average annual $\mathrm{N}_{2} \mathrm{O}$ fluxes from these sites but rather to look for changes in $\mathrm{N}_{2} \mathrm{O}$ flux and $\mathrm{N}$ availability (and their relation to one another). The large number of sites in this chronosequence study would, in part, compensate for the limited temporal sampling.

\section{Methods}

\subsection{Site description}

The study was conducted near Santarém $\left(2^{\circ} 25^{\prime} \mathrm{S}, 54^{\circ} 47^{\prime} \mathrm{W}\right)$ in the state of Pará, Brazil. The landscape consists of a mosaic of old growth forests, pasture land, agricultural fields and secondary forests. The region has a mean annual temperature of $25^{\circ} \mathrm{C}$ and a mean relative humidity of $86 \%$. Annual rainfall is highly variable and averages about $2000 \mathrm{~mm}$ with a dry season lasting usually from August to October (Parrotta et al., 1995). The sites we selected for our study were mainly situated on deep, well-drained clayey Oxisols (kaolinitic yellow latosols in the Brazilian classification system, Embrapa, 1999) with some soils transitional to Ultisols (red-yellow podzolic soils in the Brazilian classification system, Embrapa, 1999) also present in the region (Silver et al., 2000).

We conducted a regional survey between 50 and $100 \mathrm{~km}$ south of Santarém at the beginning of the rainy season in $1999 / 2000$ on a chronosequence of pasture sites $(n=27)$ of contrasting ages (between 6 months to 60 years following deforestation). Two undisturbed old-growth forest sites served as reference plots. Pastures younger than 10 years were established by manual clearing during the dry season. On pastures older than 10 years, bulldozers were also used for removal of trees. Typically, isolated valuable and protected tree species, especially Brazil nut trees, were left in the fields. Slashed and dried biomass was partly burned shortly before the onset of the rainy season. On most sites, grass seeds were either sown directly or after one rotation of maize or rice (10 sites). Typical management of the pasture sites consisted of slashing of secondary vegetation once per year and burning about once every three years $(n=17)$ or by a yearly rotation of slashing and burning $(n=9)$. Fire favors the dominance of pasture grasses over secondary vegetation and enhances the palatability of grasses. Invading accidental fires from adjacent areas are common. No fertilizers were used on any of the pastures. Except for the 6 month and 1 year old pastures, all sites were actively grazed at an average annual rate of about 1 animal ha ${ }^{-1}$.

Brachiaria brizantha (A. Rich.) Stapf cv. Marandu was the dominant grass species at most sites. Only the 1 year old site was planted with "mombaça" (Panicum maximum Jacq.) and the 60 year old pasture site was planted with "quicuio" (Brachiaria humidicola). All pasture sites of our chronosequence study contained woody vegetation including trees left 
standing following forest clearing and/or regrowing shrubs. Woody vegetation was more prominent in younger pasture sites where single trees were left standing and residual uncombusted woody debris still remained from the old growth forests.

\section{$2.2 \mathrm{~N}_{2} \mathrm{O}$ and $\mathrm{CH}_{4}$ flux measurements}

Surface fluxes of $\mathrm{N}_{2} \mathrm{O}$ and $\mathrm{CH}_{4}$ were assayed once during both wet and dry season using two-part static vented chambers (PVC and ABS plastics) approximately $20 \mathrm{~cm}$ high (Keller and Reiners, 1994). At each site 7-8 chamber bases were installed along at randomly selected points along a $50 \mathrm{~m}$ long transect. The chamber bases were inserted into the soil to a depth of $2-3 \mathrm{~cm}$ about 5 to $10 \mathrm{~min}$ prior to chamber closure. Four $20 \mathrm{ml}$ headspace samples were withdrawn at 10 -min intervals over $30 \mathrm{~min}$ using nylon syringes fitted with polycarbonate/polypropylene valves. The syringes were transported to the laboratory for analysis by ECD $\left(\mathrm{N}_{2} \mathrm{O}\right)$ and FID $\left(\mathrm{CH}_{4}\right)$ gas chromatography within $36 \mathrm{~h}$ of sampling. Integrated peak areas for samples were compared to known standards for determination of gas mixing ratio. Fluxes were calculated from the linear change of mixing ratio with time for the brief enclosures. Fluxes of $\mathrm{N}_{2} \mathrm{O}$ were discarded when the initial sample (1 min following enclosure) greatly exceeded the ambient mixing ratio of $\sim 310 \mathrm{ppbv}$. When fewer than 4 chamber measurements per site were obtained, the entire site was excluded. Zero fluxes (no change in concentration) were included.

\subsection{Soil sampling and processing}

Surface soil $(10 \mathrm{~cm}$ depth $)$ was sampled once during the rainy season (April-May) and once during the dry season (September-October) of 2000. Soil cores were taken adjacent to 4 chambers with a root corer of $7 \mathrm{~cm}$ diameter, transferred in sealed plastic bags and transported in Styrofoam coolers to the laboratory the same day. Coarse roots, stones and litter were manually removed from the samples. Bulk density measurements $(0-5 \mathrm{~cm}$ depth) were made using undisturbed soil cores. Subsamples for determination of particle size distribution, $\mathrm{pH}$ and exchangeable cations were air-dried, ground and passed through a 2-mm sieve. Air-dried subsamples (taking during the rainy season) for total nitrogen $(\mathrm{N})$ and inorganic phosphorus $(\mathrm{Pi})$ were ground to $<150 \mu \mathrm{m}$ using a ball mill. Field moist subsamples (of both wet and dry season sampling) for enzyme analysis (protease activity), microbial biomass $\mathrm{N}$ measurement and inorganic $\mathrm{N}$ and $\mathrm{N}$-mineralization determination were passed through a 2-mm sieve and stored at $4^{\circ} \mathrm{C}$ until analysis.

\subsection{Soil physical and chemical analyses}

Soil bulk density (BD) was measured using the core method (Anderson and Ingram, 1993). Particle size distribution was analyzed with the pipette method using pyrophosphate as a dispersing agent (Moschrefi, 1983). Soil $\mathrm{pH}$ was determined in a slurry of $10 \mathrm{~g}$ soil and $25 \mathrm{ml}$ de-ionized water (Anderson and Ingram, 1993). Gravimetric water content was calculated as the ratio of mass of water to soil dry mass after ovendrying soil at $105^{\circ} \mathrm{C}$ for $24 \mathrm{~h}$. Total $\mathrm{N}$ was measured with an automated $\mathrm{C}$ and $\mathrm{N}$ analyzer (Elementaranalysator CNS, Vario EL, elementar, Hanau, Germany) (König and Fortman, 1996). Inorganic $\mathrm{P}(\mathrm{Pi})$ was determined by resin extraction (Tiessen and Moir, 1993). Exchangeable calcium (Ca), magnesium $(\mathrm{Mg})$, potassium $(\mathrm{K})$ and aluminum $(\mathrm{Al})$ were extracted by leaching soil samples with $100 \mathrm{ml}$ of unbuffered $1 \mathrm{M}$ ammonium chloride $\left(\mathrm{NH}_{4} \mathrm{Cl}\right)$ for 4-5 h. Cations in the extracts were quantified by atomic absorption spectroscopy (König and Fortmann, 1996).

Nitrate $\left(\mathrm{NO}_{3}^{-}\right)$and ammonium $\left(\mathrm{NH}_{4}^{+}\right)$were determined by extracting $10 \mathrm{~g}$ of field moist soil with $70 \mathrm{ml}$ of $2 \mathrm{M} \mathrm{KCl}$. The soil- $\mathrm{KCl}$ solution was shaken for an hour on a horizontal shaker and allowed to settle for $2 \mathrm{~h}$. A 20-ml aliquot of the supernatant was removed with a syringe, filtered through a $0.45 \mu \mathrm{m}$ polysulfone membrane and stored frozen until analysis (Erickson et al., 2001). Analysis of $\mathrm{NH}_{4}^{+}$and $\mathrm{NO}_{3}^{-}$was done on a continuous-flow autoanalyzer (Skalar, Erkelenz, Germany) according to König and Fortmann (1996).

Potential net mineralization and net nitrification were measured using the aerobic incubation procedure described by Hart et al. (1994). Two $10 \mathrm{~g}$ sub-samples of field moist soil were transferred into $100 \mathrm{ml}$ polyethylene plastic bottles. One set of sub-samples was immediately extracted with $70 \mathrm{ml}$ of $2 \mathrm{M} \mathrm{KCl}$, the other set was covered with perforated parafilm and incubated for 7 days at ambient temperature in the dark before extraction. Ammonium and $\mathrm{NO}_{3}^{-}$were analyzed as described above. Net mineralization and nitrification rates were calculated from the difference between inorganic $\mathrm{N}$ at the beginning and end of the incubation, and results were expressed as $\mu \mathrm{g} \mathrm{N}$ released per $\mathrm{g}$ of dry soil over 7 days.

\subsection{Soil microbiological assays}

Protease activity (N-benzoyl-L-argininamide hydrolysis) of the soil was determined according to Bonmati et al. (1998). The released $\mathrm{NH}_{4}^{+}$was measured according to the procedure of Kandeler and Gerber (1988). Results of activity are expressed as $\mu \mathrm{g} \mathrm{NH}_{4}^{+}$released per $\mathrm{g}$ of dry soil per hour.

Beta-glucosidase activity in the soil was measured according to Eivazi and Tabatabai (1988). Toluene was not included in the procedure. Results of enzyme activity is expressed as micrograms p-nitrophenol (PNP) released per g of dry soil per hour and are averages of triplicate assays.

Microbial biomass $\mathrm{N}$ was analyzed by the chloroformfumigation-extraction method of Vance et al. (1987). Soil was adjusted to $30 \%$ water holding capacity (WHC) prior to fumigation and extraction. Total organic $\mathrm{N}$ of the $\mathrm{K}_{2} \mathrm{SO}_{4}$ extracts was oxidized to $\mathrm{NO}_{3}^{-}$by $\mathrm{UV}$ and persulphate digestion, and the released $\mathrm{NO}_{3}^{-}$was measured on a continuous 

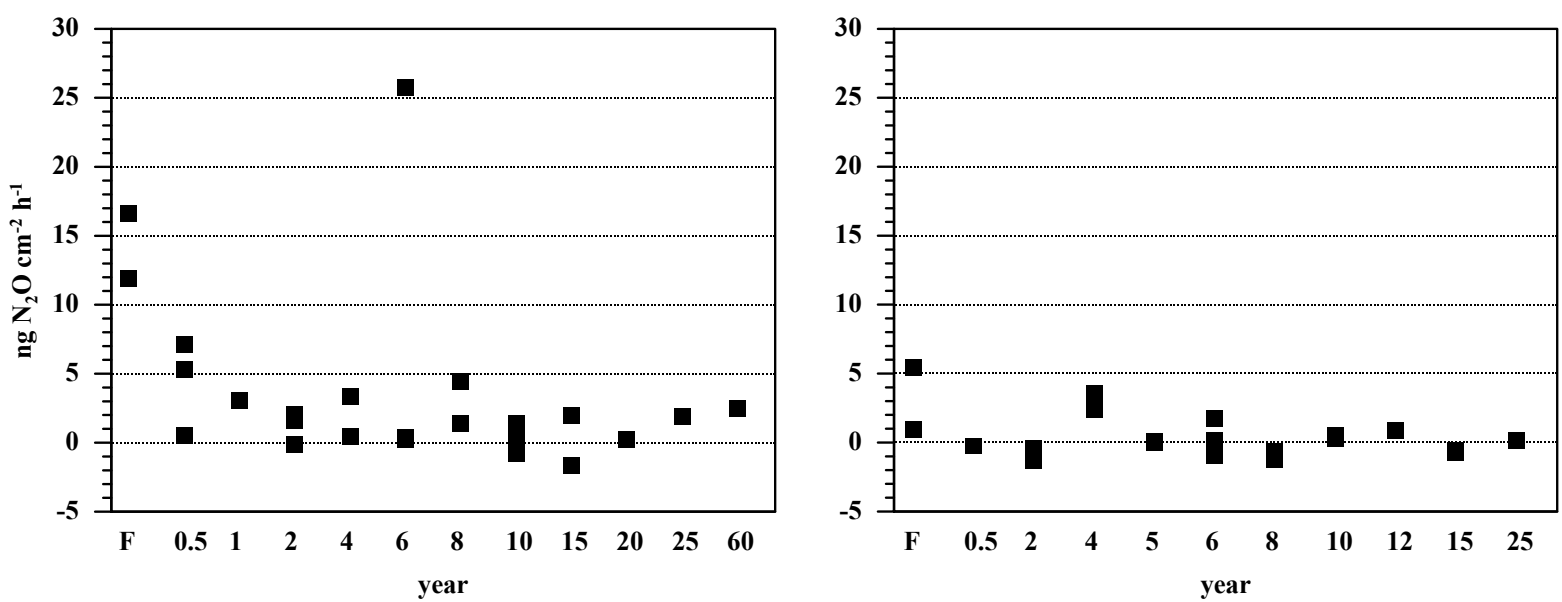

Fig. 1. Fluxes of $\mathrm{N}_{2} \mathrm{O}\left(\mathrm{ng} \mathrm{N} \mathrm{N}_{2} \mathrm{O}-\mathrm{N} \mathrm{cm}^{-2} \mathrm{~h}^{-1}\right.$ ) from forest and pasture soils during the wet season (left) and the dry season (right) of 2000, near Santarém, Pará, Brazil.

flow autoanalyzer (Skalar, Erkelenz, Germany) (König and Fortman, 1996). Microbial biomass $\mathrm{N}$ was calculated by subtracting extractable $\mathrm{N}$ in the unfumigated sample from extractable $\mathrm{N}$ in the fumigated sample (Vance et al., 1987) divided by the $\mathrm{K}_{E N}$ factor of 0.54 (Brookes et al., 1985).

\subsection{Plant sampling and analysis}

Wet and dry season standing grass biomass and grass litter at each pasture site was sampled from 2 points along the transect using a $1-\mathrm{m}^{2}$ frame. Subsamples were dried at $65^{\circ} \mathrm{C}$ and ground to $<150 \mu \mathrm{m}$ on a ballmill. Total $\mathrm{C}$ and $\mathrm{N}$ were measured with an automated $\mathrm{C}$ and $\mathrm{N}$ analyzer (Elementaranalysator CNS, Vario EL, elementar, Hanau, Germany) (König and Fortman, 1996). For comparison to pasture biomass, we used data of forest floor litter stocks including data from Silver et al. (2000).

\subsection{Statistical analyses}

Fluxes of $\mathrm{N}_{2} \mathrm{O}$ and soil variables (log transformed where necessary) were compared using analysis of variance separately for wet and dry seasons with three pasture age classes. Pasture sites were clustered in young ( 0 to 2 years, $n=8$ ), intermediate ( 4 to 8 years, $n=9$ ) and old age classes ( $>10$ years, $\mathrm{n}=10$ ). The Tukey-Kramer test at the $95 \%$ confidence level was used for post-hoc comparison of class means to account for unequal sample sizes.

The relationship between $\mathrm{N}_{2} \mathrm{O}$ fluxes and the various soil parameters were evaluated using the linear regression procedures from SYSTAT version 10.2 (SYSTAT, 2002). Number of sites were $\mathrm{n}=2$ for old growth forests, $\mathrm{n}=3$ for 6 months old pastures, $n=1$ for 1 year old pasture, $n=4$ for 2 year old pastures, $\mathrm{n}=2$ for 5 year old pastures, $\mathrm{n}=3$ for 6 year old pastures, $\mathrm{n}=2$ for 8 year old pastures, $\mathrm{n}=4$ for 10 year old pasture, $\mathrm{n}=1$ for 12 year old pasture, $n=2$ for 15 year old pasture, and $n=1$ for each 20, 25 and 60 year old pastures.

\section{Results}

3.1 General soil characteristics of the forest and pasture sites

All sites of our chronosequence study had a clayey to very clayey texture according to the Brazilian classification system (Embrapa, 1999). Clay content varied between 36 and $78 \%$ in the top $10 \mathrm{~cm}$ of all sites except for one forest site which had a clay content of $25 \%$ (Table 1). Soil bulk density (BD) was below $1 \mathrm{Mg} \mathrm{m}^{-3}$ at the old growth forest and 6 months old pasture site and increased with pasture age to about $1.2 \mathrm{Mg} \mathrm{m}^{-3}$ in the 15 to 25 year old pastures.

Total $\mathrm{N}$ of forest and pasture soils up to 8 years old was generally between 2.1 and $2.6 \mathrm{~g} \mathrm{~N} \mathrm{~kg}^{-1}$ soil (Table 1) and was lower in pastures older than 10 years associated with the higher sand content in older pastures (Table 1).

Soil $\mathrm{pH}$ in the forests was 3.9 and between 4.0 and 5.6 in the pasture soils. Forest clearing, burning and pasture establishment increased soil $\mathrm{pH}$ and concomitantly decreased available $\mathrm{Al}$ at all pasture sites. Concentrations of basic cations $\mathrm{Ca}$ (Table 1) and $\mathrm{Mg}$ and $\mathrm{K}$ (data not shown) increased considerably after deforestation and pasture establishment. Calcium concentrations remained elevated in the pasture sites for up to 12 years after deforestation relative to the forest sites and declined consistently in pastures older than 15 years. Inorganic phosphorous (Pi) was highest in the old growth forest soils and the young pastures of 6 months and 1 year. With increasing pasture age Pi decreased steadily.

\subsection{Fluxes of $\mathrm{N}_{2} \mathrm{O}$ and $\mathrm{CH}_{4}$ from forest and pasture soils}

Six months following forest clearing and pasture establishment $\mathrm{N}_{2} \mathrm{O}$ fluxes were $67 \%$ lower compared to the primary forests (Fig. 1). Fluxes of $\mathrm{N}_{2} \mathrm{O}$ were higher during the wet than during the dry season and showed no consistent trend with pasture age. During the wet season, pasture sites 
Table 1. Average soil physical and chemical characteristics of the top $10 \mathrm{~cm}$ of old growth forests and pasture soils during the wet and dry season of 2000, near Santarém, Pará, Brazil.

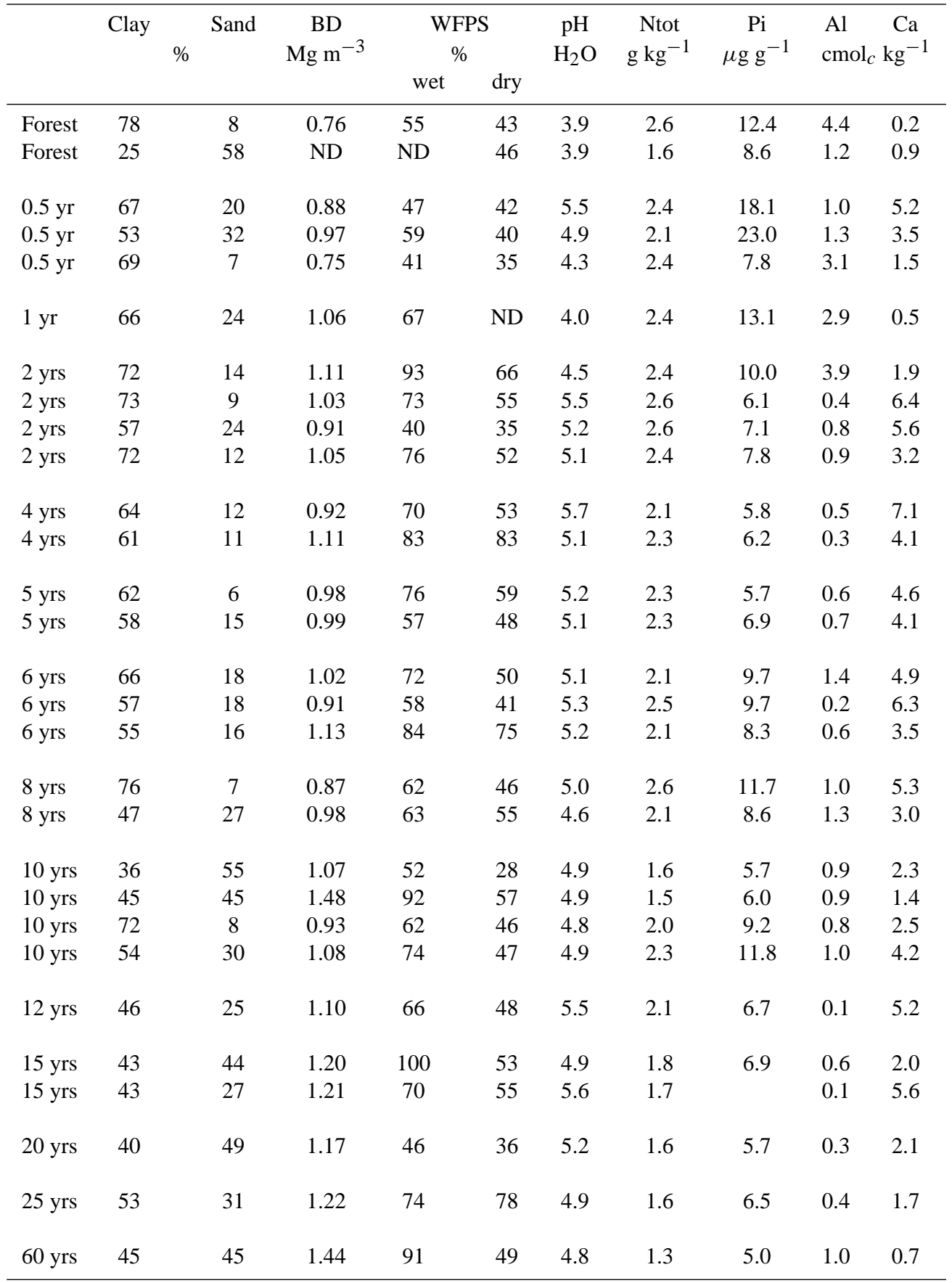

$\mathrm{ND}=$ not determined

generally had lower fluxes than forest sites except for the $\mathrm{N}_{2} \mathrm{O}$ fluxes of one 6 year old pasture site which exceeded forest $\mathrm{N}_{2} \mathrm{O}$ fluxes by $50 \%$. During the dry season emissions of $\mathrm{N}_{2} \mathrm{O}$ from pasture sites were significantly lower than from forest soils and some pasture soils showed slight net uptake of $\mathrm{N}_{2} \mathrm{O}$. Nitrous oxide emissions of the 4 year old pasture sites were comparable to fluxes from the forest sites. Fluxes of $\mathrm{N}_{2} \mathrm{O}$ from young, intermediate and old pasture classes were not significantly different from one other.

Forest soils consumed $\mathrm{CH}_{4}$ during both wet season and dry season at similar rates (Fig. 2). During the wet season young pastures up to one year generally consumed $\mathrm{CH}_{4}$ 

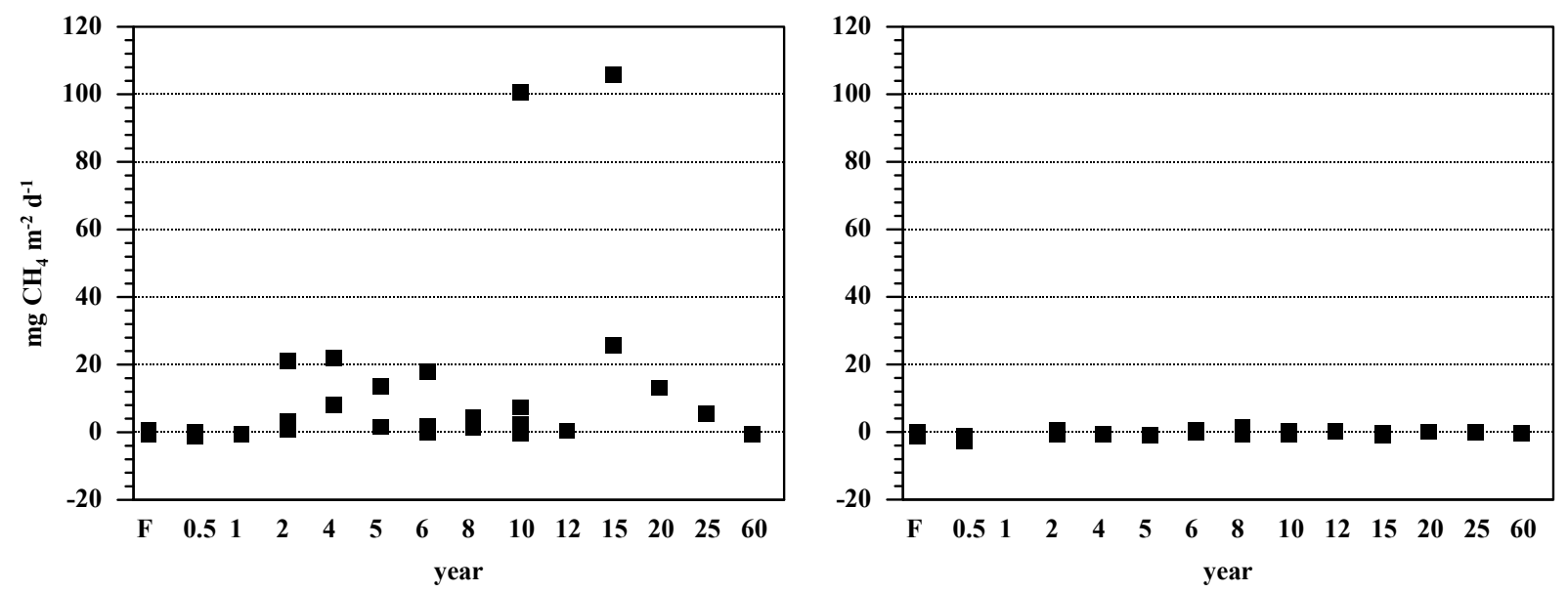

Fig. 2. Fluxes of $\mathrm{CH}_{4}\left(\mathrm{mg} \mathrm{m}^{-2} \mathrm{~d}^{-1}\right)$ from forest and pasture soils during the wet season (left) and the dry season (right) of 2000, near Santarém, Pará, Brazil.
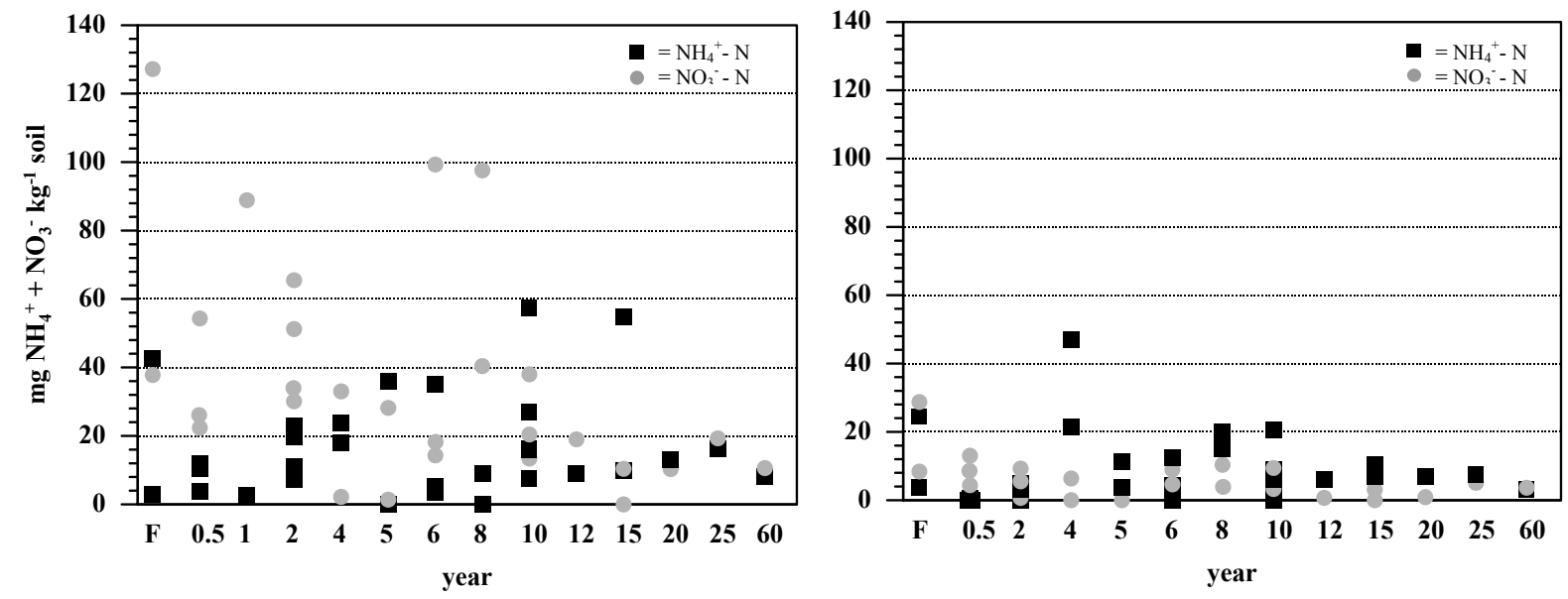

Fig. 3. Inorganic $\mathrm{N}$-pools ( $\mathrm{mg} \mathrm{NH} \mathrm{NH}_{4}^{+}$and $\mathrm{NO}_{3}^{-}-\mathrm{N}$ per kilogram soil) from forest and pasture soils during the wet season (left) and the dry season (right) of 2000, near Santarém, Pará, Brazil.

whereas most pastures older than 1 year emitted $\mathrm{CH}_{4}$ to the atmosphere. Emissions of $\mathrm{CH}_{4}$ were not significantly different among young, intermediate and old pasture age classes. During the dry season forest and most pastures soils consumed $\mathrm{CH}_{4}$ but no clear trend with pasture age was observed. The uptake rates were similar between pastures and the old growth forest. We found no significant relationships between $\mathrm{CH}_{4}$ fluxes and indices of $\mathrm{N}$ cycling or inorganic $\mathrm{N}$ stocks or between $\mathrm{CH}_{4}$ fluxes and soil moisture, BD or soil chemical characteristics.

3.3 Nitrogen cycling and turnover in forest and pasture soils

Total inorganic N-pools $\left(\mathrm{NO}_{3}^{-}-\mathrm{N}\right.$ and $\left.\mathrm{NH}_{4}^{+}-\mathrm{N}\right)$ were greater during the wet than during the dry season and showed no consistent trend with pasture age (Fig. 3). Nitrate was the dominant form of inorganic $\mathrm{N}$ at our old growth forest sites during both wet and dry season. At the pasture sites $\mathrm{NO}_{3}^{-}$$\mathrm{N}$ generally dominated the inorganic $\mathrm{N}$ pools during the wet season whereas $\mathrm{NH}_{4}^{+}-\mathrm{N}$ was the dominant form of inorganic $\mathrm{N}$ in the pasture soils during the dry season. Extractable $\mathrm{NH}_{4}^{+}-\mathrm{N}$ did not differ significantly among forest and pasture classes during either wet or dry season. During the wet season, extractable $\mathrm{NO}_{3}^{-}-\mathrm{N}$ concentrations in young pastures of $0-2$ years were similar to the forest sites. Pastures older than 4 years had significantly lower extractable $\mathrm{NO}_{3}^{-}-\mathrm{N}$ compared to the forest sites. No significant differences among the pasture classes was found. During the dry season, forest $\mathrm{NO}_{3}^{-}-\mathrm{N}$ concentrations were significantly higher than in pasture soils. No statistically significant differences of $\mathrm{NO}_{3}^{-}-\mathrm{N}$ concentrations were found among the pasture classes.

Potential net $\mathrm{N}$-mineralization and net nitrification rates were generally higher during the wet season than during the dry season (Fig. 4). At the forest sites nitrification rates were 

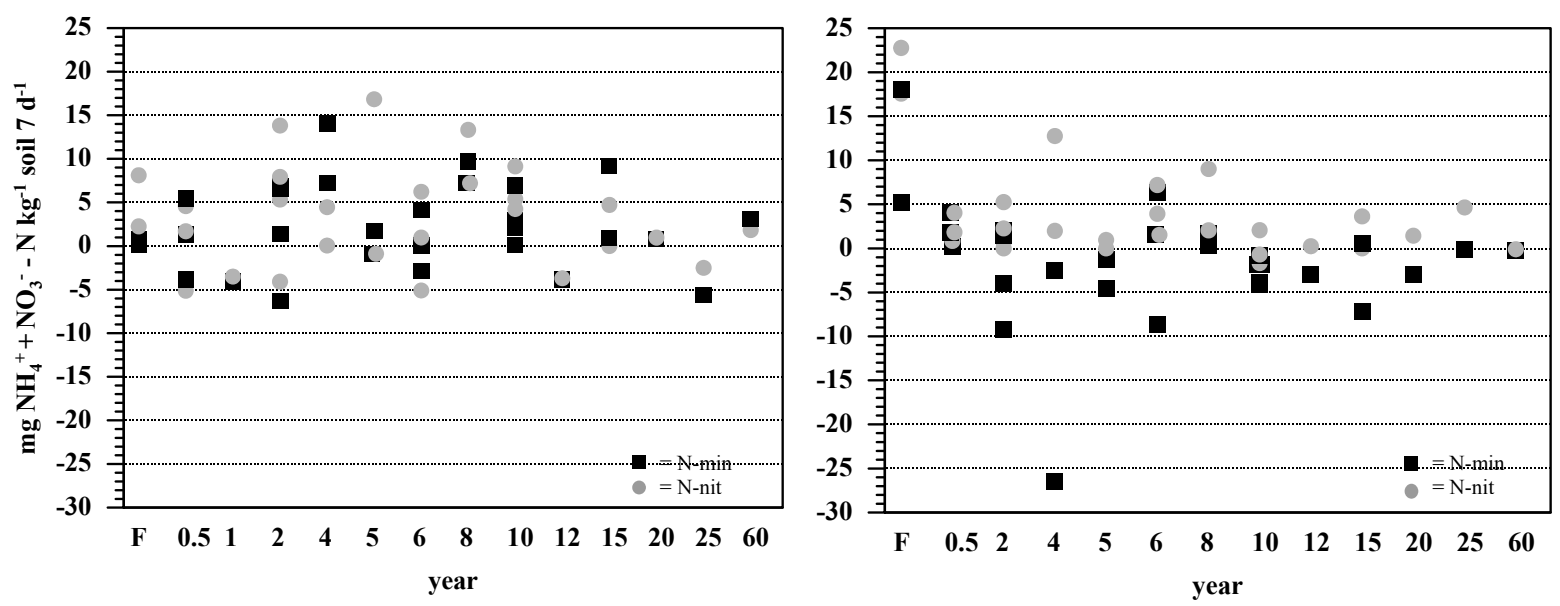

Fig. 4. Potential $\mathrm{N}$-mineralization $\left(\mathrm{mg} \mathrm{NH}_{4}^{+}\right.$and $\left.\mathrm{NO}_{3}^{-}-\mathrm{N}\right)$ and nitrification rates $\left(\mathrm{mg} \mathrm{NO}_{3}^{-}-\mathrm{N}\right)$ over 7 days in the laboratory from forest and pasture soils during the wet season (left) and the dry season (right) of 2000, near Santarém, Pará, Brazil.
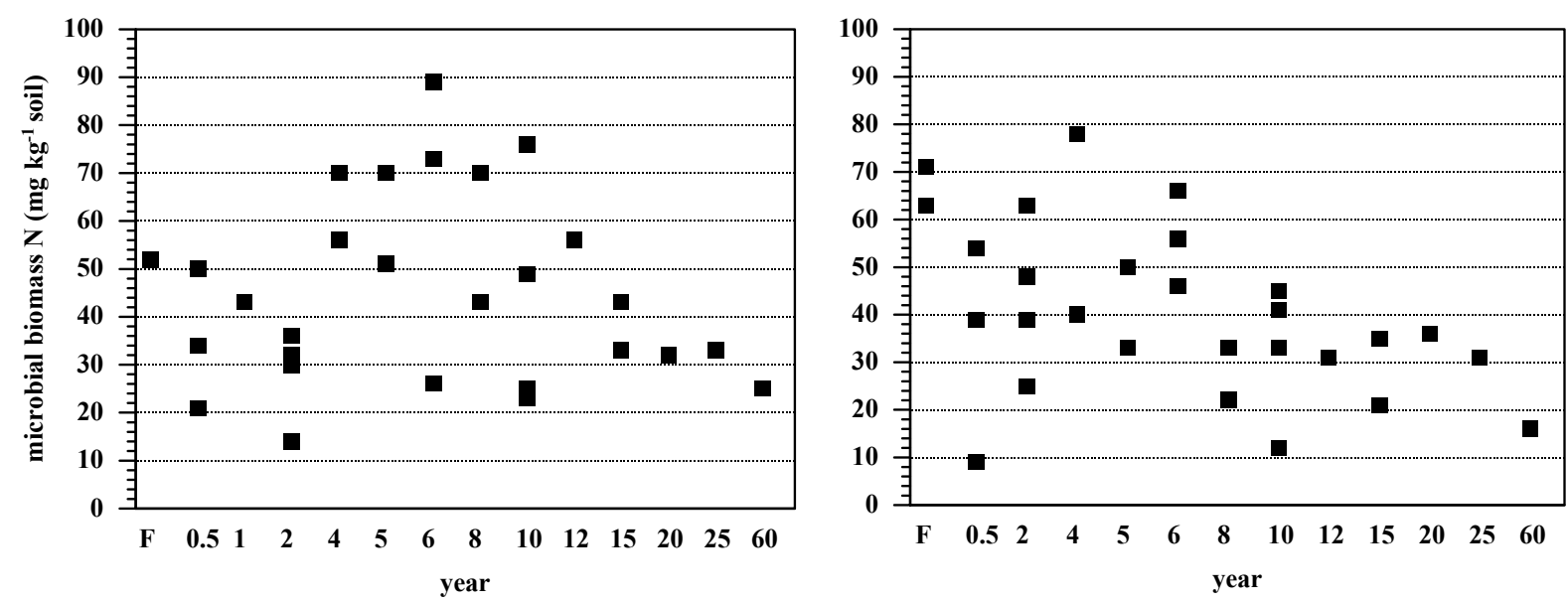

Fig. 5. Microbial biomass $\mathrm{N}\left(\mathrm{mg} \mathrm{N} \mathrm{kg}^{-1}\right.$ soil) from forest and pasture soils during the wet season (left) and the dry season (right) of 2000, near Santarém, Pará, Brazil.

higher than $\mathrm{N}$-mineralization rates during both wet and dry season. During the dry season, most pastures older than 1 year showed net immobilization and nitrification exceeded $\mathrm{N}$-mineralization. During the wet season no statistically significant differences in potential $\mathrm{N}$ mineralization and nitrification rates were found among forest and pasture classes. During the dry season, forest sites had significantly higher $\mathrm{N}$ mineralization and nitrification rates than the pasture classes which, in turn, did not differ significantly from one another.

Microbial biomass $\mathrm{N}$ during the wet season (Fig. 5) was significantly higher in the 4 to 8 year-old pasture class as compared to the young pasture class ( 0 to 2 years). However, there were no statistically significant differences among other sampled classes. During the dry season, the microbial biomass $\mathrm{N}$ in the forest soils was similar to the intermediate pasture age class of 4 to 8 years whereas both young and old pasture age classes had significantly lower microbial biomass
$\mathrm{N}$ than the forest sites. No significant differences were found among the pasture age classes.

The protease activity in forest and pasture sites was lower during the wet than during the dry season (Fig. 6). No statistically significant differences were found among forest and pasture classes during either the wet or dry season.

The $\mathrm{C} / \mathrm{N}$ ratio of litter was low at the forest sites and increased with pasture age up to 10 years (Fig. 7). No clear trend was found in pastures older than 10 years. The $\mathrm{C} / \mathrm{N}$ ratio increased consistently from about 25 in both the 6 month and 1 year old sites to about 70 in the 15 to 25 year old sites. The forest litter $\mathrm{C} / \mathrm{N}$ ratio was similar to young pasture sites ( $0-2$ years) whereas pastures older than 4 years had significantly higher $\mathrm{C} / \mathrm{N}$ ratios than the forest sites. The young pasture age class had significantly lower $\mathrm{C} / \mathrm{N}$ ratios than the old pasture age class. The increase of the $\mathrm{C} / \mathrm{N}$ ratio with pasture age was accompanied by a decrease in overall pasture 

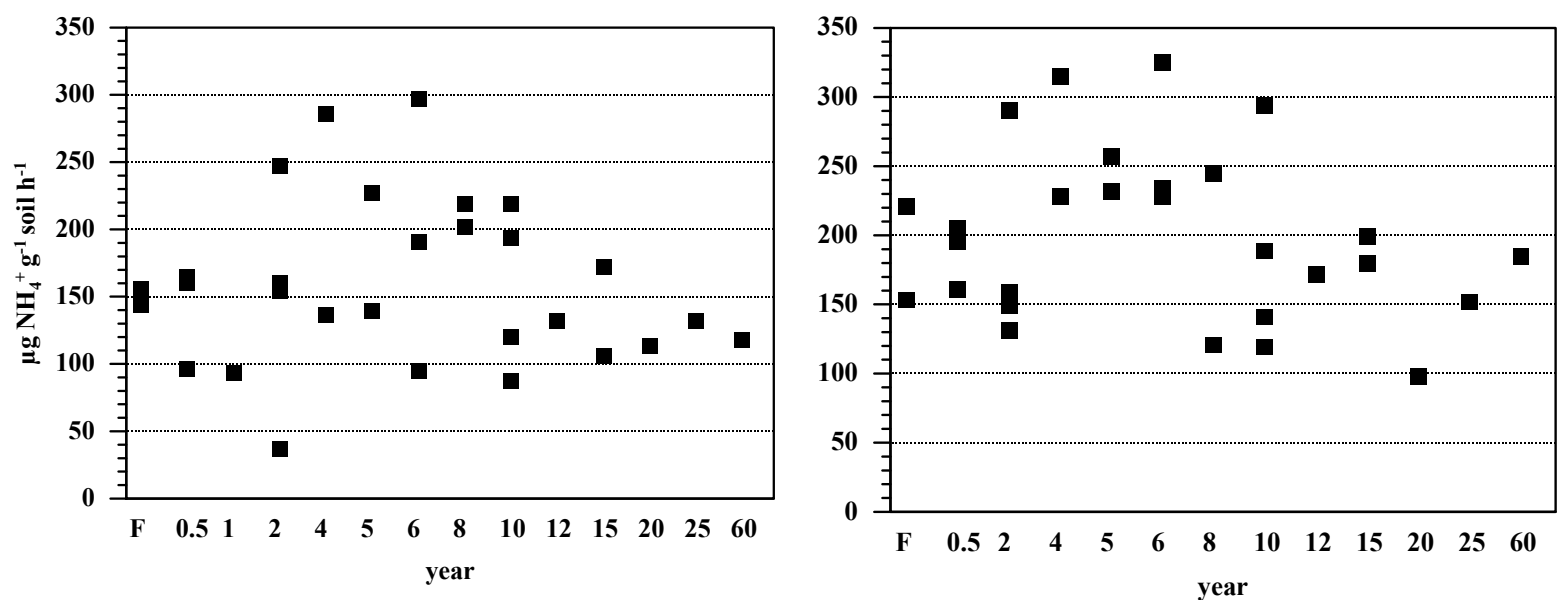

Fig. 6. Protease activity ( $\mu \mathrm{g} \mathrm{NH}_{4}^{+}-\mathrm{N} \mathrm{g}^{-1}$ soil $\mathrm{h}^{-1}$ ) from forest and pasture soils during the wet season (left) and the dry season (right) of 2000, near Santarém, Pará, Brazil.

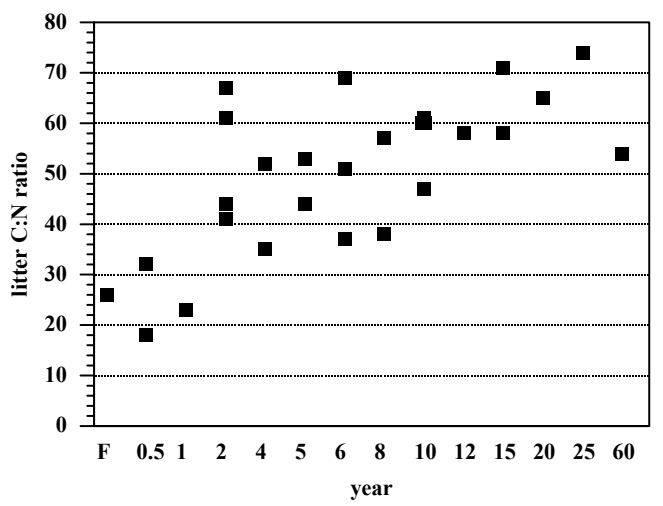

Fig. 7. Litter C/N ratio from forest and pasture soils of 2000, near Santarém, Pará, Brazil.

productivity and site degradation as was reflected by sparse soil cover. Total aboveground grass biomass decreased from about $10 \mathrm{tha}^{-1}$ in the 1 to 10 year old pasture sites to about $5 \mathrm{tha}^{-1}$ on average in pastures older than 10 years (data not shown).

\section{Discussion}

4.1 Changes of $\mathrm{N}$ transformation along the forest-topasture chronosequence

The pasture chronosequence showed a strong decline in most measures of $\mathrm{N}$ cycling with time following deforestation. The dominance of nitrate over ammonium pools in our forest soils is consistent with results by Matson et al. (1990) and Neill et al. (1995) for humid tropical forest ecosystems in the central and western Brazilian Amazon. While recognizing that nitrate pool sizes do not give information on $\mathrm{N}$ transformation rates, nitrate accumulation has been inter- preted as an indication of an open, leaky soil $\mathrm{N}$ cycle, that leaches nitrate, and may be indicative of gaseous $\mathrm{N}$ losses such as $\mathrm{N}_{2} \mathrm{O}$ (Vitousek et al., 1982). This interpretation was supported by results of our aerobic incubations. In our forest soils, net nitrification exceeded net $\mathrm{N}$-mineralization which indicates the potential for $\mathrm{N}$ losses by gaseous emission or leaching (e.g. Vitousek and Sanford, 1986; Matson and Vitousek, 1987). In the pastures of our chronosequence, the internal soil $\mathrm{N}$ cycle drastically changed compared to the forest sites. While young pastures still display dominance of nitrate over ammonium in the wet season, the clear drop of nitrate concentrations in the older pastures and the dominance of ammonium in the dry season indicate that the internal $\mathrm{N}$ cycle of these pastures is more closed. This is supported by low mineralization and nitrification rates, both of which even became negative (net immobilization, Fig. 4) in a considerable number of pastures.

Increasing $\mathrm{N}$ limitation with pasture age was reflected in the decrease in litter quality of Brachiaria brizantha with age (Fig. 7), a trend that has also been observed in old pastures in other studies (Castilla and Jackson, 1996; Fernandes et al., 2002). A pattern of increased $\mathrm{N}$ limitation with increasing pasture age has also been observed in forest-topasture chronosequence studies in Rondônia (Neill et al., 1995, 1999) and in Costa Rica (Veldkamp et al., 1999). Progressive $\mathrm{N}$ limitation with pasture age is probably caused by a combination of early loss of nitrogen through gaseous emissions and leaching, reduced inputs of nitrogen (e.g. by $\mathrm{N}$ fixation) and the immobilization of $\mathrm{N}$ by grass litter and roots with a high C-to-N ratio. Brachiaria brizantha deposits large quantities of litter and decaying roots of very low $\mathrm{N}$ content of 0.5 to $1 \%$ (Boddey et al., 1996). Furthermore in pastures, the microbial biomass gradually reworks soil organic matter (SOM) to more recalcitrant forms that cycle $\mathrm{N}$ more slowly as compared with SOM in the original forest (Neill et al., 1999). 


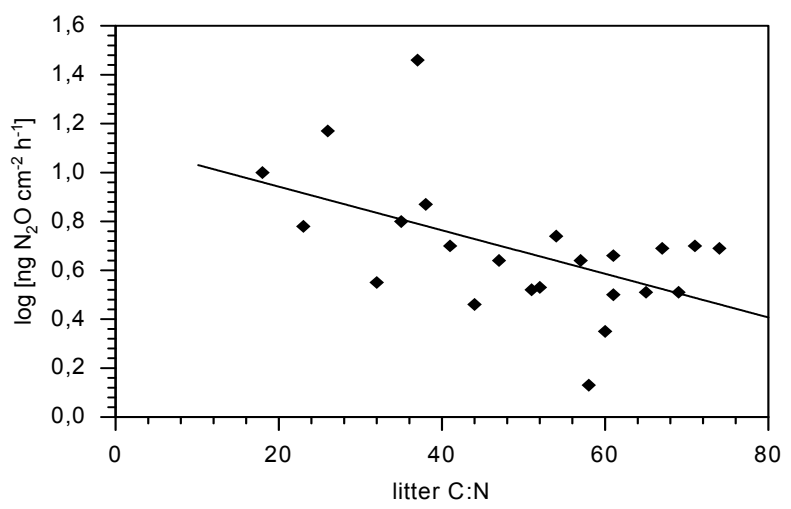

Fig. 8a. Linear regression of wet season $\log$ transformed $\mathrm{N}_{2} \mathrm{O}$ fluxes with litter $\mathrm{C} / \mathrm{N}$ ratio $\left[\log \mathrm{N}_{2} \mathrm{O}=-0.009 * \operatorname{litter} \mathrm{C} / \mathrm{N}+1.12\right.$, $\mathrm{R}^{2}=0.28, \mathrm{p}=0.01, \mathrm{n}=23$ ] during 2000 from a forest-to-pasture chronosequence near Santarém, Pará, Brazil.

The strong decline of microbial biomass $\mathrm{N}$ following deforestation that we observed has also been reported for young pasture sites near Manaus, in the central Amazon (Luizão et al., 1992). Apart from the direct lethal effects of heat, the effect of burning probably limited microbial growth for some time after felling and burning due to changes in substrate availability (Raison, 1979; Kauffman et al., 1995). Slash burning in Amazonian forests is accompanied by a temporary input of low quality, high $\mathrm{C} / \mathrm{N}$ debris to soils (Kauffman et al., 1995). The peak of microbial biomass $N$ in the 4 to 6 year old pasture sites (wet season) with a high aboveground biomass production is probably related to the large (-above-) and sub-surface inputs of organic material from shoots, roots, and root residues returning labile $\mathrm{C}$ and nutrients to the soil as was found in other studies in Brazil (Boddey et al., 1996; Neill et al., 1999). The aboveground biomass in the intermediate pasture age classes was $12 \mathrm{tha}^{-1}$ compared to $8 \mathrm{tha}^{-1}$ in both the young and old pasture sites. The steady decline of the microbial biomass in the pastures of 8 years and older may be a result of pasture degradation caused by the combined effects of reduced nutrient stocks, lower plant biomass and related lower organic matter return with a higher $\mathrm{C} / \mathrm{N}$ ratio.

Extracellular proteases are involved in the mineralization of organic $\mathrm{N}$ compounds to amino acids and subsequent ammonification from amino acids to ammonia and $\mathrm{CO}_{2}$ (Loll and Bollag, 1983; Kalisz, 1988). In our chronosequence study we observed a close correlation between microbial biomass $\mathrm{N}$ and protease activity ( $\mathrm{r}=0.71, \mathrm{p}>0.001, \mathrm{n}=28$ ). The observed pattern of protease activity was probably also related to changes in substrate quality. As soil proteases are limited by available substrate concentrations (Tateno, 1988), high activity in intermediate pastures and decreasing activities in older pasture sites was likely due to changes in availability of nitrogen containing organic compounds as pastures aged. In older pastures with a high litter $\mathrm{C} / \mathrm{N}$ ratio

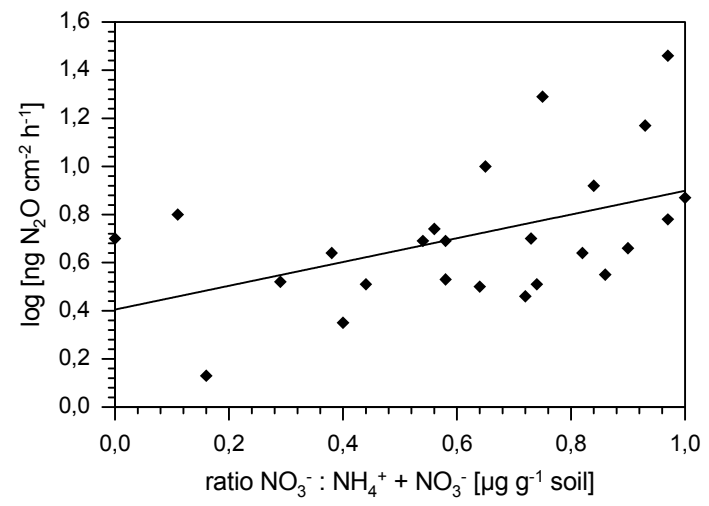

Fig. 8b. Linear regression of wet season $\log$ transformed $\mathrm{N}_{2} \mathrm{O}$ fluxes with the ratio $\mathrm{NO}_{3}^{-}: \mathrm{NH}_{4}^{+}+\mathrm{NO}_{3}^{-}\left[\log \mathrm{N}_{2} \mathrm{O}=0.497 *\right.$ ratio $\left.\mathrm{NO}_{3}^{-}: \mathrm{NH}_{4}^{+}+0.403, \mathrm{R}^{2}=0.23, \mathrm{p}=0.016, \mathrm{n}=25\right]$ during 2000 from a forest-to-pasture chronosequence near Santarém, Pará, Brazil.

$\mathrm{N}$ is rapidly immobilized by the microbial biomass and, after turnover of the microbial population, may be sequestered into the recalcitrant humic soil pool over time (Hall and Matson, 2003).

\subsection{Factors controlling $\mathrm{N}_{2} \mathrm{O}$ fluxes from forest and pasture sites}

Although we sampled $\mathrm{N}_{2} \mathrm{O}$ fluxes only twice, our measured $\mathrm{N}_{2} \mathrm{O}$ fluxes correlated with several indices of $\mathrm{N}$ cycling, suggesting that $\mathrm{N}$ availability exerted an important control on $\mathrm{N}_{2} \mathrm{O}$ fluxes. As was found by Erickson et al. $(2001,2002)$ and Davidson et al. (2000), $\mathrm{N}_{2} \mathrm{O}$ fluxes in our study were negatively correlated with the litter quality of the forest and pasture biomass (Fig. 8a). The $\mathrm{C} / \mathrm{N}$ ratio of litter has been proposed as reasonable proxy for $\mathrm{N}$ availability in ecosystems (Davidson et al., 2000) and is an important determining factor whether $\mathrm{N}$ is mineralized or immobilized. Litter high in $\mathrm{N}$ is associated with fast rates of decomposition and rapid soil $\mathrm{N}$ turnover which, in turn, may result in increased emissions of $\mathrm{N}_{2} \mathrm{O}$ (Erickson et al., 2001, 2002).

The positive correlation with the ratio of $\mathrm{NO}_{3}^{-}-\mathrm{N}$ to the sum of $\mathrm{NH}_{4}^{+}-\mathrm{N}$ and $\mathrm{NO}_{3}^{-}-\mathrm{N}$ which we observed during the wet season (Fig. 8b) and the positive correlation between fluxes of $\mathrm{N}_{2} \mathrm{O}$ and the sum of $\mathrm{NH}_{4}^{+}-\mathrm{N}$ and $\mathrm{NO}_{3}^{-}-\mathrm{N}$ during the dry season (Fig. 8c) fit the conceptual model of Firestone and Davidson (1989), Davidson et al. (2000) and Davidson and Verchot (2000). In this model, commonly called "Holein-the-Pipe", the first level of control on $\mathrm{N}_{2} \mathrm{O}$ fluxes is the rate of nitrogen cycling through ecosystems. The contribution from nitrification (biological oxidation of $\mathrm{NH}_{4}^{+}$) to $\mathrm{N}_{2} \mathrm{O}$ production can be significant at certain sites (Firestone and Davidson, 1989; Hall and Matson, 2003).

Although we found no correlation of $\mathrm{N}_{2} \mathrm{O}$ fluxes with WFPS, we think that soil aeration content played an important role in some of the observed $\mathrm{N}_{2} \mathrm{O}$ emissions. 


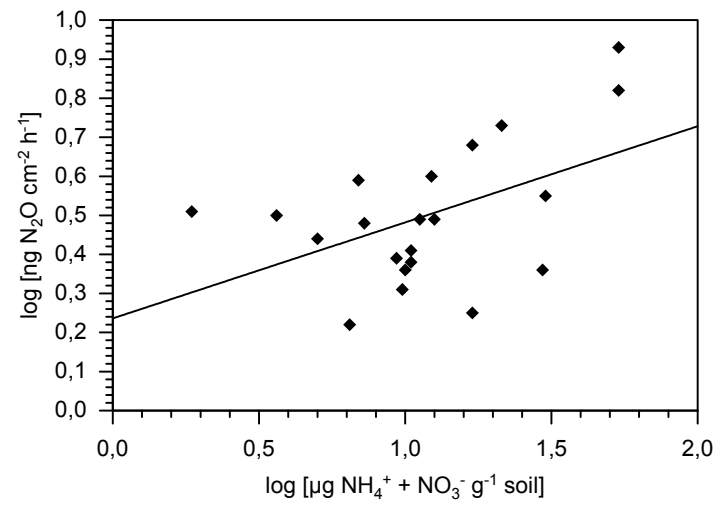

Fig. 8c. Linear regression of dry season $\log$ transformed $\mathrm{N}_{2} \mathrm{O}$ fluxes with $\log \mathrm{NH}_{4}^{+}+\mathrm{NO}_{3}^{-}\left[\log \mathrm{N}_{2} \mathrm{O}=0.244 * \log \left(\mathrm{NO}_{3}^{-}+\mathrm{NH}_{4}^{+}\right)+0.239\right.$, $\mathrm{R}^{2}=0.23, \mathrm{p}=0.026, \mathrm{n}=21$ ] during 2000 from a forest-to-pasture chronosequence near Santarém, Pará, Brazil.

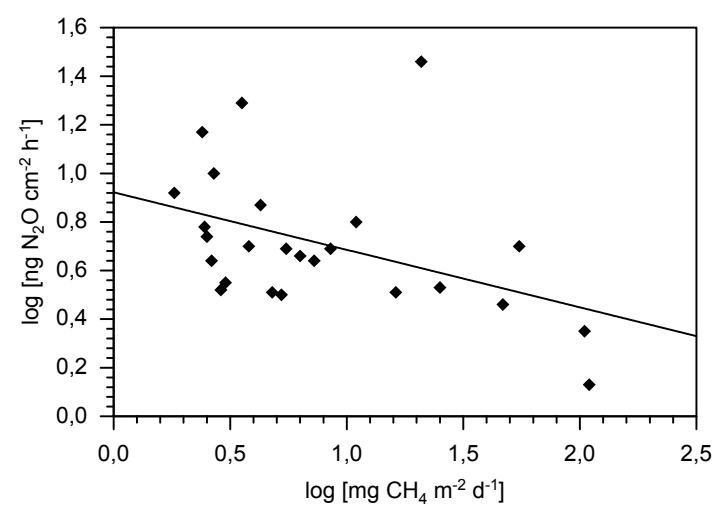

Fig. 8d. Linear regression of wet season log transformed $\mathrm{N}_{2} \mathrm{O}$ fluxes with $\log \mathrm{CH}_{4}+50\left[\log \mathrm{N}_{2} \mathrm{O}=-0.239 * \log \mathrm{CH}_{4}+0.92\right.$, $\mathrm{R}^{2}=0.19, \mathrm{p}=0.03, \mathrm{n}=25$ ] during 2000 from a forest-to-pasture chronosequence near Santarém, Pará, Brazil.

Negative correlations were found between $\mathrm{N}_{2} \mathrm{O}$ fluxes and $\mathrm{CH}_{4}$ emissions (Fig. 8d) in the wet season. Furthermore, chambers in which we measured the highest methane emissions often corresponded with low or even negative $\mathrm{N}_{2} \mathrm{O}$ emissions (results not shown). These results correspond to findings by Keller et al. (1986) and suggest that at least in some pastures strongly anaerobic conditions prevailed during the wet season, which may have led to reduction of $\mathrm{N}_{2} \mathrm{O}$ to $\mathrm{N}_{2}$. Apart from the reduced $\mathrm{N}$ availability in older pastures this may have been an additional cause for the observed low (and sometimes negative) $\mathrm{N}_{2} \mathrm{O}$ fluxes.

An additional control on $\mathrm{N}_{2} \mathrm{O}$ emissions may have been easily available carbon as was illustrated by the correlation of $\mathrm{N}_{2} \mathrm{O}$ emission with $\beta$-glucosidase activity in the dry season (Fig. 8f). Beta-glucosidase plays a key role in the decomposition of carbohydrates in soils (Shewale, 1982), and the products of $\beta$-glucosidase activity are believed to be an important substrate for microbial metabolism. Especially heterotrophic

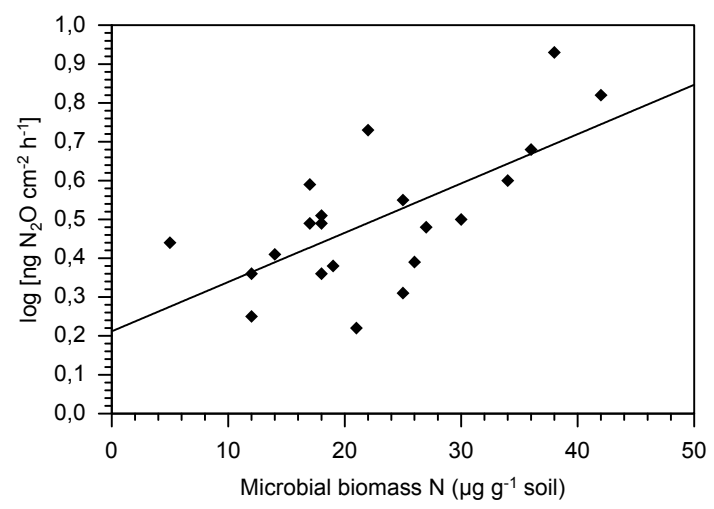

Fig. 8e. Linear regression of dry season $\log$ transformed $\mathrm{N}_{2} \mathrm{O}$ fluxes with microbial biomass $\mathrm{N}\left[\log \mathrm{N}_{2} \mathrm{O}=0.012 * \mathrm{Nmic}+0.221, \mathrm{R}^{2}=0.43\right.$, $\mathrm{p}=0.001, \mathrm{n}=21]$ during 2000 from a forest-to-pasture chronosequence near Santarém, Pará, Brazil.

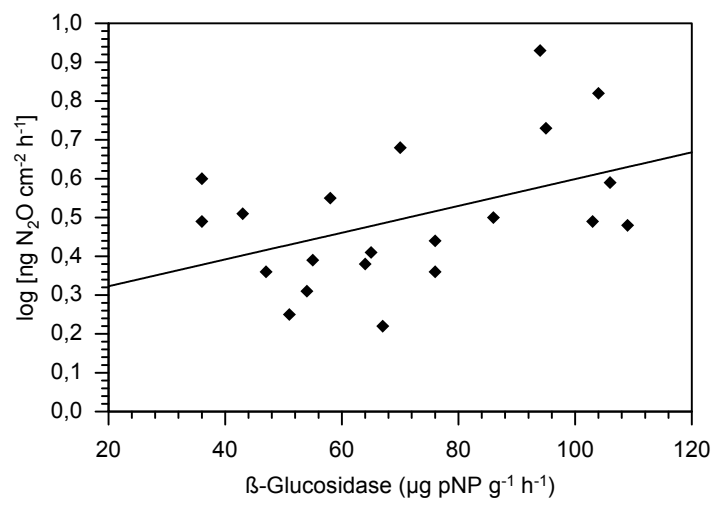

Fig. 8f. Linear regression of dry season $\log$ transformed $\mathrm{N}_{2} \mathrm{O}$ fluxes with $\beta$-Glucosidase activity [ $\log \mathrm{N}_{2} \mathrm{O}=0.003^{*} \beta$ glucosidase $+0.258, \mathrm{R}^{2}=0.20, \mathrm{p}=0.042, \mathrm{n}=21$ ] during 2000 from a forest-to-pasture chronosequence near Santarém, Pará, Brazil.

nitrifying and denitrifying bacteria (which can both produce $\mathrm{N}_{2} \mathrm{O}$ ) require an organic form of carbon as energy source and may depend on $\beta$-glucosidase activity for their carbon supply. The importance of available carbon for $\mathrm{N}_{2} \mathrm{O}$ production has been discussed before (Groffman, 1991) and positive correlations between $\mathrm{N}_{2} \mathrm{O}$ emissions and $\beta$-glucosidase activities have also been established for temperate wetland soils (Freeman et al., 1997; Kang et al., 1998).

\subsection{Regional comparison of $\mathrm{N}_{2} \mathrm{O}$-fluxes in the Amazon basin}

Forest clearing can result in a pulse of available soil $\mathrm{N}$ and may cause transient increases in $\mathrm{N}_{2} \mathrm{O}$ emissions (Keller et al., 1993; Melillo et al., 2001). The magnitude and duration of $\mathrm{N}_{2} \mathrm{O}$ emissions following deforestation and pasture establishment differs among the central and eastern Brazilian Amazon on one hand and the western Brazilian Amazon on the other hand. Our results from 2 forest sites and 27 
pasture sites in the central Amazon agree with other studies conducted in the central and eastern Amazon (Goreau and de Mello, 1985, 1988; Verchot et al., 1999); $\mathrm{N}_{2} \mathrm{O}$ fluxes from forest soils were relatively high and $\mathrm{N}_{2} \mathrm{O}$ fluxes from pasture soils were always lower. The dominance of nitrate over ammonium and the dominance of nitrification over $\mathrm{N}$ mineralization during the wet season (Figs. 2 and 3) may indicate that in pastures younger than 10 years there is some potential for higher $\mathrm{N}_{2} \mathrm{O}$ emissions. However, we only measured high $\mathrm{N}_{2} \mathrm{O}$ fluxes on one 6 year old pasture site.

Our results agree also with observations from Rondônia, western Amazon for pastures older than 3 years (GarciaMontiel et al., 2001) but do not agree with higher emissions from young pastures up to 2-3 years relative to forest (Melillo et al., 2001). The temporary increases of $\mathrm{N}_{2} \mathrm{O}$ in Rondônia immediately following forest clearing may be explained by different soil conditions. In contrast to the clay-textured Oxisols in central and eastern Amazon, soils in Rondônia are coarser textured Ultisols. This difference in texture may lead to rapid SOM turnover and $\mathrm{N}$ mineralization rates in Rondônia (Desjardins et al., 1994; Moraes et al., 1996; Neill et al., 1999), whereas in the eastern Amazon, the higher clay content may protect SOM against rapid mineralization (Koutika et al., 1997). Furthermore, the variation in soil mineralogy on $\mathrm{P}$ availability likely contributed to the differences in pasture productivity and $\mathrm{N} \mathrm{cy-}$ cling across the Amazon basin (see Davidson et al., 2004). The phosphorus status of pastures on Ultisols in Rondônia is better (see Garcia-Montiel et al., 2000) than the pastures in this study (Table 1) or a nearby study on forest-to pasture chronosequences (Asner et al., 2004), and in the Paragominas region, eastern Amazon (see Verchot et al., 1999). The better P status at the Rondônian sites may have led to higher pasture productivity and hence, the potential of increased levels of SOM and N-mineralization. In contrast to Rondônia, studies in Paragominas (Trumbore et al., 1995) and central Amazonia (Wick, unpublished results) show declining SOM levels in (-unfertilized-) pastures.

Overall, this study confirms the results from a forest-topasture chronosequence in Paragominas, eastern Amazon on similar soils and management regimes (Verchot et al., 1999) that young pastures do not emit higher $\mathrm{N}_{2} \mathrm{O}$ compared to the forests that they replaced. Excess $\mathrm{N}$, easily available carbon and soil water content controlled fluxes of $\mathrm{N}_{2} \mathrm{O}$.

Acknowledgements. We gratefully acknowledge support from the German Research Foundation (DFG), the German Agency for Technical Cooperation (GTZ), the NASA Terrestrial Ecology Program (NASA NCC5-225 and NCC5-357), the US Forest Service and US AID. This work was done as part of the Brazilian led Large Scale Biosphere-Atmosphere Experiment in Amazonia (LBA). We also thank E. Davidson for the constructive review of an earlier version of this manuscript.

Edited by: J. Chanton

\section{References}

Anderson, J. M. and Ingram, J. S. I.: Tropical Soil Biology and Fertility. A Handbook of Methods, 2nd Edition, CAB International, Wallingford, UK, 1993.

Asner, G. P., Townsend, A. R., Bustamante, M. M. C., Nardoto, G. B., and Olander, L. P.: Pasture degradation in the central Amazon: linking changes in carbon and nutrient cycling with remote sensing, Global Change Biology, 10, 844-862, 2004.

Boddey, R. M., Rao, I. M., and Thomas, R. J.: Nutrient cycling and environmental impact of Brachiaria pastures, in: Brachiaria: Biology, Agronomy, and Improvement, edited by: Miles, J. W., Maass, B. L., Valle, C. B., with the collaboration of Kumble, V., Publication no 259, Centro International de Agricultura Tropical, Cali, Colombia, 72-86, 1996.

Bonmati, M., Ceccanti, B., and Nannipieri, P.: Protease extraction from soil by sodium pyrophosphate and chemical characterization of the extracts, Soil Biology and Biochemistry, 30, 21132125, 1998.

Brookes, P. C., Landman, A., Pruden, G., and Jenkinson, D. S.: Chloroform fumigation and the release of soil nitrogen: a rapid extraction method for measuring microbial biomass nitrogen in soil, Soil Biology and Biochemistry, 17, 837-842, 1985.

Castilla, C. and Jackson, W. A.: Nitrogen uptake mechanism in two Brachiaria species: Y-315, in: Brachiaria: Biology, Agronomy, and Improvement, edited by: Miles, J. W., Maass, B. L., Valle, C. B., with the collaboration of Kumble, V., Publication no 259, Centro International de Agricultura Tropical, Cali, Colombia, p. 57, 1996.

Davidson, E. A., Keller, M., Erickson, H. E., Verchot, L. V., and Veldkamp, E.: Testing a conceptual model of soil emissions of nitrous and nitric oxides, BioScience, 50(8), 667-680, 2000.

Davidson, E. A. and Verchot, L. V.: Testing the hole-in-the-pipe model of nitric and nitrous oxide emissions from soils using the TRAGNET database, Global Biogeochemical Cycles, 14 (4), 1035-1043, 2000.

Davidson, E. A., Neill, C., Krusche, A. V., Ballester, V. V. R., Markewitz, D., and de O. Figueiredo, R.: Loss of nutrients from terrestrial ecosystems to streams and the atmosphere following land use change in Amazonia, Ecological Applications, 14, 147158, 2004.

Desjardins, T., Andreaux, F., Volkoff, B., and Cerri, C. C.: Organic carbon and ${ }^{13} \mathrm{C}$ contents in soils and soil size-fractions, and their changes due to deforestation and pasture installation in eastern Amazonia, Geoderma, 61, 103-118, 1994.

Eivazi, F. and Tabatabai, M. A.: Glucosidases and galactosidases in soils, Soil Biology and Biochemistry, 20(5), 601-606, 1988.

Embrapa: Sistema Brasileiro de Classificação de solos, 1st edition, Servico de Produção de Informação- SPI, Brasília, DF, Brazil, 412 p., 1999.

Erickson, H., Keller, M., and Davidson, E. A.: Nitrogen oxide fluxes and nitrogen cycling during postagricultural succession and forest fertilization in the humid tropics, Ecosystems, 4, 6784, 2001.

Erickson, H., Davidson, E. A., and Keller, M.: Former land-use and tree species affect nitrogen oxide emissions from a tropical dry forest, Oecologia, 130, 297-308, 2002. 
Fernandes, S. A. P., Bernoux, M., Cerri, C. C., Feigl, B. J., and Piccolo, M. C.: Seasonal variation of soil chemical properties and $\mathrm{CO}_{2}$ and $\mathrm{CH}_{4}$ fluxes in unfertilized and $\mathrm{P}$-fertilized pastures in an Ultisol of the Brazilian Amazon, Geoderma, 107, 227-241, 2002.

Firestone, M. K. and Davidson, E. A.: Microbiological basis of NO and $\mathrm{N}_{2} \mathrm{O}$ production and consumption in soil, in: Exchange of trace gases between terrestrial ecosystems and the atmosphere, edited by: Andreae, M. O. and Schimel, D. S., Chichester, John Wiley and Sons, Chichester, UK, 7-21, 1989.

Fleming, R. A.: Statistical advantages in, and characteristics of, data from long-term research, The Forestry Chronicle, 75 (3), 487-489, 1999.

Freeman, C., Liska, G., Ostle, N. J., Lock, M. A., Hughes, S., Reynolds, B., and Hudson, J.: Enzymes and biogeochemical cycling in wetlands during a simulated drought, Biogeochemistry, 39, 177-187, 1997.

Garcia-Montiel, D. C., Neill, C., Melillo, J. M., Thomas, S., Steudler, P. A., and Cerri, C. C.: Soil phosphorus transformations following forest clearing for pasture in the Brazilian Amazon, Soil Science Society of America, 64, 1792-1804, 2000.

Garcia-Montiel, D. C., Steudler, P. A., Piccolo, M. C., Melillo, J. M., Neill, C., and Cerri, C. C.: Controls on soil nitrogen oxide emissions from forest and pastures in the Brazilian Amazon, Global Biogeochem Cycles, 15 (4), 1021-1030, 2001.

Goreau, T. J. and de Mello, W. Z.: Effects of deforestation on sources and sinks of atmospheric carbon dioxide, nitrous oxide, and methane from central Amazonian soils and biota during the dry season: a preliminary study, in: Biogeochemistry of Tropical Rain Forests: Problems for Research, edited by: Athié, D., Lovejoy, T. E., and de Marez Oyens, P., Piricicaba: Centro do Energia Nuclear na Agricultura, and World Wildlife Fund, Piricicaba, São Paulo, Brazil, 51-66, 1985.

Goreau, T. J. and de Mello, W. Z.: Tropical Deforestation: some effects on atmospheric chemistry, Ambio, 17 (4), 275-281, 1988.

Groffman, P. M.: Ecology of nitrification and denitrification in soil evaluated at scales relevant to atmospheric chemistry, in: Microbial production and consumption of greenhouse gases, edited by: Roger, J. E., Whitman, W. B., Washington D. C., American Society for Microbiology, Washington D. C., 91-110, 1991.

Hall, S. J. and Matson, P. A.: Nutrient status of tropical rain forests influences soil $\mathrm{N}$ dynamics after $\mathrm{N}$ additions, Ecological Monographs, 73 (1), 107-129, 2003.

Hart, S. C., Stark, J. M., Davidson, E. A., and Firestone, M. K.: Nitrogen mineralization, immobilization, and nitrification, in: Methods of Analysis, Part 2, Microbiological and Biochemical Properties, Madison, Soil Science Society of America Book Series no 5, Madison, USA, 985-1018, 1994.

Houghton, R. A., Skole, D. L., Nobre, C. A., Hackler, J. L., Lawrence, K. T., and Chomentowski, W. H.: Annual fluxes of carbon from the deforestation and regrowth in the Brazilian Amazon, Nature, 403 (6767), 301-304, 2000.

IPCC: Climate Change 2001: The Scientific basis, Contribution of working group I to the third assessment report of the intergovernmental panel on climate change, Cambridge University Press, London, 92-94, 2001.

Kalisz, H. M.: Microbial proteinases, Advances in Biochemical Engineering/Biotechnology, 36, 3-65, 1988.
Kandeler, E. and Gerber, H.: Short-term assay of soil urease activity using colorimetric determination of ammonium, Biology and Fertility of Soils, 6, 68-72, 1988.

Kang, H., Freeman, C., and Lock, M. A.: Trace gas emissions from a North Wales fen - role of hydrochemistry and soil enzyme activity, Water, Air, and Soil Pollution, 105, 107-116, 1998.

Kauffman, J. B., Cunnings, D. L, Ward, D. E., and Babbitt, R.: Fire in the Brazilian Amazon. 1. Biomass, nutrient pools and losses in cattle pastures, Oecologia, 113, 415-427, 1995.

Keller, M., Kaplan, W. A., and Wofsy, S. C.: Emissions of $\mathrm{N}_{2} \mathrm{O}$, $\mathrm{CH}_{4}$ and $\mathrm{CO}_{2}$ from tropical forest soils, J. Geophys. Res., 91 (D11), 11 791-11 802, 1986.

Keller, M., Veldkamp, E., Weitz, A. M., and Reiners, W. A.: Effect of pasture age on soil trace gas emissions from a deforested area of Costa Rica, Nature, 365, 224-246, 1993.

Keller, M. and Reiners, W. A.: Soil-atmosphere exchange of nitrous oxide, nitric oxide, and methane under secondary succession of pasture to forest in the Atlantic lowlands of Costa Rica, Global Biogeochem Cycles, 8 (4), 399-409, 1994.

König, N. and Fortmann, H.: Probenvorbereitungs-, Untersuchungs- und Elementbestimmungs-Methoden des Umweltanalytik-Labors der Niedersächsischen Forstlichen Versuchsanstalt, 1-4, Berichte des Forschungszentrums Waldökosysteme, Reihe B, University of Göttingen, Germany, B46-B49, ISSN 0939-1339, 1996.

Koutika, L. S., Bartoli, F., Andreaux, F., Cerri, C. C., Burtin, G., Choné, T., and Philippy, R.: Organic matter dynamics and aggregation in soils under rain forest and pastures of increasing age in the eastern Amazon basin, Geoderma, 76, 87-11, 1997.

Loll, M. J. and Bollag, J. M.: Protein transformation in soil, Advances in Agronomy, 36, 351-382, 1983.

Luizão, F., Matson, P., Livingston, G., Luizão, R. R. C., and Vitousek, P.: Nitrous oxide fluxes following tropical land clearing, Global Biogeochem Cycles, 3 (3), 281-285, 1989.

Luizão, R. C. C., Bonde, T. A., Rosswall, T.: Seasonal variation of soil microbial biomass - the effects of clearfelling a tropical rainforest and establishment of pasture in the central Amazon, Soil Biology and Biochemistry, 24, 805-813, 1992.

Matson, P. A. and Vitousek P. M.: Cross-system comparisons of soil nitrogen transformations and nitrous oxide flux in tropical forest ecosystems, Global Biogeochemical Cycles, 1, 163-170, 1987.

Matson, P. A., Vitousek, P. M., Livingston, G. P., and Swanberg, N. A.: Sources of variation in nitrous oxide flux from Amazonian ecosystems, J. Geophys. Res., 95 (D 10), 16 789-16 798, 1990.

Melillo, J. M., Steudler, P. A., Feigl, B. A., Neill, C., Garcia, D., Piccolo, M. C., Cerri, C. C., and Tian, H.: Nitrous oxide emissions from forests and pastures of various ages in the Brazilian Amazon, J. Geophys. Res., 106, 34 179-34 188, 2001.

Moraes, J. F. L., Volkhoff, B., Cerri, C. C., and Bernoux, M.: Soil properties under Amazon forest and changes due to pasture installation in Rondônia, Brazil, Geoderma, 70, 63-81, 1996.

Moschrefi, N.: Ein neues Verfahren der Schlämmanalyse für die Bestimmung der Korngrößenzusammensetzung, Mitteilungen der Deutschen Bodenkundlichen Gesellschaft, 38, 115-118, 1983.

Mosier, A. R. and Delgado, J. A.: Methane and nitrous oxide fluxes in grasslands in western Puerto Rico, Chemosphere, 35, 20592082, 1997. 
Neill, C., Piccolo, M. C., Steudler, P. A., Melillo, J. M., Feigl, B., and Cerri, C. C.: Nitrogen dynamics in soils of forests and active pastures in the western Brazilian Amazon basin, Soil Biology and Biochemistry, 27 (9), 1167-1175, 1995.

Neill, C., Piccolo, M. C., Melillo, J. M., Steudler, P. A., and Cerri, C. C.: Nitrogen dynamics in Amazon forest and pasture soils measured by $15 \mathrm{~N}$ pool dilution, Soil Biology and Biochemistry, 31, 567-572, 1999.

Nepstad, D. C., Klink, C. A., Uhl, U., Vieira, I. C., Lefebvre, P., Pedlowski, M., Matricardi, E., Negreiros, G., Brown, I. F., Amaral, E., Homma, A., and Walker, R.: Land-use in Amazonia and the Cerrado of Brazil, Ciencia e Cultura Journal of the Brazilian Association for the Advancement of Science, 49, 73-85, 1997.

Parrotta, J. A., Francis, J. K., and de Almeida, R. R.: Trees of the Tapajos. A photographic field guide, Rio Piedras, Puerto Rico, United States Department of Agriculture, Forest Service, International Institute of Tropical Forestry, General Technical Report IITF-1, 1995.

Pickett, S. T. A.: Space-for-time substitution as an alternative to long-term studies, in: Long-term studies in ecology, New York, edited by: Likens, G. E., Springer Verlag New York, 110-135, 1989.

Plant, R. A. J.: Regional analysis of soil-atmosphere nitrous oxide emissions in the Northern Atlantic Zone of Costa Rica, Global Change Biology, 6, 639-653, 2000.,

Raison R. J.: Modification of the soil environment by vegetation fires, with particular reference to nitrogen transformations: a review, Plant and Soil, 51, 73-108, 1979.

Reiners, W. A. S., Liu, K. G., Gerow, M., Keller, M., and Schimel, D. S.: Historical and future land use effects on $\mathrm{N}_{2} \mathrm{O}$ and No emissions using an ensemble modeling approach: Costa Rica's Caribbean lowlands as an example, Global Biogeochemical Cycles, 16(4), 1068, doi:10.1029/2001GB001437, 2002.

Shewale, J. G.: Beta-glucosidase: its role in cellulase synthesis and hydrolysis of cellulose, International Journal of Biochemistry, 14, 435-443, 1982.

Silver, W. L., Neff, J., McGroddy, M., Veldkamp, E., Keller, M., and Cosme, R.: Effects of soil texture and belowground carbon and nutrient storage in a lowland Amazonian Forest Ecosystem, Ecosystems, 3, 193-209, 2000.
SYSTAT for Windows: Statistics, Version 10.2 Edition, Evanston, Illinois, USA, 2002.

Tateno, M.: Limitations of available substrates for the expression of cellulase and protease activities in soil, Soil Biology and Biochemistry, 20 (1), 117-118, 1988.

Tiessen, H. and Moir, J. O.: Characterization of available phosphorus by sequential extraction, in: Soil sampling and Methods of Analysis, edited by: Carter, M. R., Canadian Society of Soil Science, Lewis Publishers, USA, 75-86, 1993.

Trumbore, S. E., Davidson, E. A., Demarco, P. B., Nepstad, D. C., and Martinelli, L. A.: Belowground cycling of carbon in forests and pastures of eastern Amazonia, Global Biogeochemical Cycles, 9, 515-528, 1995.

Vance, E. D., Brookes, P. C., and Jenkinson, D. S.: An extraction method for measuring soil microbial biomass C, Soil Biology and Biochemistry, 19 (6), 703-707, 1987.

Veldkamp, E., Keller, M., and Nuñez, M.: Effects of pasture management on $\mathrm{N}_{2} \mathrm{O}$ and $\mathrm{NO}$ emissions from soils in the humid tropics of Costa Rica, Global Biogeochem Cycles, 12, 71-79, 1998.

Veldkamp, E., Davidson, E., Erickson, H., Keller, M., and Weitz, A.: Soil nitrogen cycling and nitrogen oxide emissions along a pasture chronosequence in the humid tropics of Costa Rica, Soil Biology and Biochemistry, 31, 387-394, 1999.

Verchot, L. V., Davidson, E. A., Cattânio, J. H., Ackerman, I. L., Erickson, H. E., and Keller, M.: Land use change and biogeochemical controls of nitrogen oxide emissions from soils of eastern Amazonia, Global Biogeochem Cycles, 13, 31-46, 1999.

Vitousek, P. M., Gosz, J. R., Grier, C. C., Melillo, J. M., and Reiners, W. A.: A comparative analysis of potential nitrification and nitrate mobility in forest ecosystems, Ecological Monographs, 52, 155-177, 1982.

Vitousek, P. M. and Sanford Jr., R. L.: Nutrient cycling in moist tropical forest, Annual Review of Ecological Systems, 17, 137$167,1986$. 